\title{
Anthropometric Correlation with Blood Glucose Level in Community Health Center Tuntungan, in Medan City
}

\author{
Rina Amelia \\ Department of Public Health, Faculty of Medicine, Sumatera Utara University, Indonesia \\ drrinaamelia@gmail.com
}

\begin{abstract}
Obesity, an excessive accumulation of fat in the body tissues, can occur throughout the body or in a certain part of the body, such as in the abdominal area known as central/abdominal obesity. Fat distribution in the body can be measured by using anthropometry conducted by measuring Body Mass Index (BMI), Waist Circumference (WC), and Waist-Hip Circumference Ratio (WHCR) to define the central obesity. Central obesity, has an effect on Blood Glucose Level (BGL) and becomes a risk factor for the onset of Type 2 diabetes. The objective of this study was to analyse the relationship between anthropometric and BGL of the community living in around Tuntungan community Health Center, in Medan City. The consecutive sampling was applied to determined 70 people who meet the criteria, and the data collected were analysed using Spearman Correlation. The results showed that the nutritional status majority $(50 \%)$ is obese. Meanwhile, the WC measurement suggested that the majority has central obesity (78.6\%), and WHCR measurement showed that the majority has central obesity $(\mathbf{7 2 . 9 \%})$. The average BGL value of was $98 \mathrm{mg} / \mathrm{dL}$. The Spearman Correlation resulted that there is no correlation between BMI with BGL ( $p>0.05$ ), there is a positive correlation between WC and BGL $(p<0.05)$, and there is a positive correlation between WHCR and BGL $(p<0.05 ; P R=20.19)$ at community health centers in the region of Tuntungan in Medan city. The study can be concluded that there is a positive correlation between WC and WHCR and BGL.
\end{abstract}

Keywords - obesity, body mass index, waist circumference, waist-hip ratio, blood glucose levels

\section{INTRODUCTION}

Obesity has become a globally pandemic worldwide and has been declared as the biggest chronical health problem in adults by the World Health Organization (WHO). WHO data revealed that more than 1.4 billion adults are overweight, and over 200 million people, nearly 300 million women, are obese [1]. In 2007, Basic Health Survey in Indonesia reported that, nationally, the general prevalence of obesity in Indonesia was $19.1 \%$ and the prevalence of central obesity in the population aged over 15 years was $18.8 \%$ [2].

Obesity is defined as an excessive accumulation of fat in the body tissues. The accumulation might take place throughout the body or in certain part of the body such as in the abdominal area and are often known as central obesity or abdominal obesity [3]. One way to measure the distribution of fat in the body is by using anthropometry; measuring the body mass index (BMI) to determine obesity in the body, and measuring waist circumference (WC) and waisthip circumference ratio (WHCR) to determine the central obesity [4].

The BMI is an obesity parameter to estimate the risk of being exposed to obesity co-morbidities a person might have [5]. The higher the BMI value, the higher the risk of getting obesity co-morbidities [6]. The distribution of body fat, especially the one accumulated in the abdomen, is a risk factor to a person's health [7]. The risk increases when the waist circumference is over $90 \mathrm{~cm}$ for men and more than $80 \mathrm{~cm}$ for women. The obesity does not only improve cholesterol levels, but also influence blood glucose level.

The obesity, especially the central one, is one of the factors that influence the onset of Type 2 diabetes disease. The excessive deposition of fat in the body can lead to insulin resistance, which affects the blood glucose level of Diabetic mellitus [6]. The ratio of waist-to-hip was significantly associated with an impairment that indicates the metabolic syndrome including elevated BGL due to insulin resistance, whereas waist circumference is closely related to heart disease atherosclerosis [8]. Meanwhile, the estimation of body fat distribution is less meaningful than that of obesity with BMI as a predictor of the most marked diabetes mellitus type 2 in women in Pirna Indian [9]. The objective of the research was to analyse The Relationship Between Anthropometric and BGL on Communities Living Surround The Community Health Center Tuntungan, Medan. 


\section{METHODS}

The design of the research was descriptive analytic with cross sectional approach. The population was all the people who live around the Community Health Center Tuntungan. The samples were determined by consecutive sampling as many as 70 people who meet the criteria. The source of research data was primary data; the data directly taken from the field during the observation. The body weight was obtained by weighing the respondents using weighing scale (a valid tool), the height, waist circumference, and hip circumference were measured using a scale with the right technique.

The data on blood glucose level (BGL) was performed by measuring BGL using fortable blood sugar check. After all data were collected, the data were analysed and statistically tested using Spearman Correlation Test as the measurement result was not normally distributed.

\section{RESULT}

TABLE I

CHARACTERISTICS OF RESPONDENTS

\begin{tabular}{|c|c|c|}
\hline Characteristics & $\begin{array}{c}\text { Frequency } \\
\text { (person) }\end{array}$ & Percentage (\%) \\
\hline Age (years) & & \\
\hline $18-30$ & 17 & 24,3 \\
\hline $31-45$ & 30 & 42,9 \\
\hline $46-60$ & 23 & 32,9 \\
\hline Gender & & \\
\hline Male & 15 & 21.4 \\
\hline Female & 55 & 78.6 \\
\hline Total & $\mathbf{7 0}$ & $\mathbf{1 0 0}$ \\
\hline
\end{tabular}

Table1 shows that the majority of the respondents in this study about 30 people or $42.9 \%$, belongs to the age group of 31 - 45 years, the majority of the respondents is female about 55 persons or $78.6 \%$.

A. Nutritional Status of The Respondents Based on Body Mass Index (BMI)

TABLE II

NUTRITIONAL STATUS BASED ON BMI

\begin{tabular}{|c|c|c|}
\hline Nutritional Status & $\begin{array}{c}\text { Frequency } \\
\text { (person) }\end{array}$ & Percentage (\%) \\
\hline Underweight & 5 & 7.1 \\
\hline Normoweight & 17 & 24.3 \\
\hline Overweight & 13 & 18.6 \\
\hline Obesity & 35 & 50 \\
\hline Total & $\mathbf{7 0}$ & $\mathbf{1 0 0}$ \\
\hline
\end{tabular}

Data reveals on Table 2 can be concluded that the majority of the respondents in this study (35 people or $50 \%$ ) suffer from obesity.

\section{B. Waist Size}

TABLE III WAIST CIRCUMFERENCE OF THE RESPONDENTS

\begin{tabular}{|c|c|c|}
\hline $\begin{array}{c}\text { Waist } \\
\text { Circumference }\end{array}$ & $\begin{array}{c}\text { Frequency } \\
\text { (person) }\end{array}$ & Percentage (\%) \\
\hline Normal & 15 & 21.4 \\
\hline Central Obesity & 55 & 78.6 \\
\hline Total & $\mathbf{7 0}$ & $\mathbf{1 0 0}$ \\
\hline
\end{tabular}

Table 3 shows that the majority of respondents (55 people or $78.6 \%$ ) has central obesity.

\section{Waist-Hip Circumference Ratio (WHCR)}

TABLE IV

WAIST-HIP CIRCUMFERENCE RATIO OF THE RESPONDENTS

\begin{tabular}{|c|c|c|}
\hline Waist-Hip Circumference & $\begin{array}{c}\text { Frequency } \\
\text { (person) }\end{array}$ & $\begin{array}{c}\text { Percentage } \\
(\mathbf{\%})\end{array}$ \\
\hline Normal & 19 & 27.1 \\
\hline Central Obesity & 51 & 72.9 \\
\hline Total & $\mathbf{7 0}$ & $\mathbf{1 0 0}$ \\
\hline
\end{tabular}

The data on Table 4 shows that the majority of respondents (51 people or $72.9 \%$ ), has central obesity.

\section{Ad Random Blood Glucose Level}

TABLE V

AD RANDOM BLOOD GLUCOSE OF THE RESPONDENTS

\begin{tabular}{|c|c|}
\hline Description & BGL Value (mg/dL) \\
\hline Mean & 98.1 \\
\hline Minimum Value & 53 \\
\hline Maximum Value & 257 \\
\hline
\end{tabular}

Based on Table 5, it can be concluded that the average value BGL of the respondents in this study is $98 \mathrm{mg} / \mathrm{dL}$.

E. Correlation Anthropometric and Blood Glucose Level and Prevalence Ratio Value

TABLE VI

CORRELATION BETWEEN BMI, WC, AND WHCR AND BGL AND PREVALENT RATIO

\begin{tabular}{|l|l|c|c|c|}
\hline No. & & Mean & BGL & $\begin{array}{c}\text { Prevalens } \\
\text { Ratio (PR) }\end{array}$ \\
\hline 1 & BMI & $\begin{array}{c}25.2 \\
\mathrm{~kg} / \mathrm{m}^{2}\end{array}$ & $\begin{array}{c}\mathrm{r}: 0.189 ; \mathbf{0 . 1 1 7} \\
(\mathrm{p}>0.05)\end{array}$ & 0,97 \\
\hline
\end{tabular}




\begin{tabular}{|l|l|c|c|c|}
\hline 2 & WC & $88.9 \mathrm{~cm}$ & $\begin{array}{c}\mathrm{r}: 0.386 ; \mathbf{p : ~ 0 . 0 1} \\
(\mathrm{p}<0.05)\end{array}$ & 1,06 \\
\hline 3 & WHCR & 0.9 & $\begin{array}{c}\mathrm{r}: 0.386 ; \\
\mathbf{p : 0 . 0 0 1}(\mathrm{p}<0.05)\end{array}$ & 20,19 \\
\hline
\end{tabular}

The data presented on Table 6 describes that the average value of the BMI of the respondents is 25.2 $\mathrm{kg} / \mathrm{m} 2$, the average value of $\mathrm{WC}$ is $88.9 \mathrm{~cm}$, the average value of Waist-Hip Circumference Ratio is 0.9. Having performed statistical tests using Spearman Correlation Test, the result shows that there is no correlation between BMI and BGL ( $p$ > $0.05)$, there is a correlation between the WC and BGL ( $p<0.05)$, and there is a correlation between waist hip circumference ratio and KGD ( $p<0.05)$ among people living surround the Community Health Center Tuntungan Medan.

The available data were analysed to evaluate the risk calculation (Prevalence Ratio). The result showed that the BMI and the BGL have PR value of 0.97. Therefore, it can be concluded that the risk of the people suffering from BGL, based on BMI calculation, is 0.97 times greater (a value close to 1 is considered neutral/not a risk).

To determine the risk from the width of the waist hip circumference ratio for BGL, the PR value was 1.06 (equal to one, the risk is neutral); therefore, it can be concluded that the risk of the people suffering from the increase of the BGL, based on the width of the WHCR, is 1.06 times greater (the value of 1 means the risk is neutral/not a risk).

To assess the risk of the width of the WC for an increase of BGL, the value of PR is 20.19 (this value is more than one); therefore, it can be concluded that the risk of the people suffering from the increase of BGL, based on the calculation of width waist hip ratio, is 20.19 times greater (the greater the RP value the greater the risk).

\section{IV.DISCUSSION}

\section{A. Characteristics of The Respondents}

The result of this research conducted on 70 respondents identified that the majority of the respondents, 30 people or $42.9 \%$, belonged to the age group of 31-45 years, of which 16 people (22.9\%) suffered from central obesity. Age plays an important role in the incidence of obesity. The older the age of the people the higher the prevalence of obesity is likely to happen as the increase of the total body fat was in line with the increase of the age [10], [11]. The total body fat increased both in absolute and in percentage of total body weight as part of the aging process. Several studies in the developing countries have proved that the body fat significantly increase at the age of over 30 years old, and in women as pregnancy tend to increase weight because fat tissue also increase.

The increase has an impact on the accumulation of free fatty acids in the body [12]. Beside obesity, the risk of being exposed to diabetes is also in line with the increase of the age, especially at the age of 40 years, because at that age the increase of glucose intolerance starts to take place. Meanwhile, the aging process causes the ability of $\beta$-cells in the pancreas to produce insulin decreases [11], [13]. The older the person, the higher the risk of having blood glucose level and impaired glucose tolerance due to the weakening of all body organs including pancreas cells that produce insulin. Changes in lifestyle are also a risk of suffering from diabetes; as a result, the age of the people being exposed to diabetes is younger than that of before [14].

\section{B. Body Mass Index of The Respondents}

The results described that the majority of the respondents were female (55 persons or $78.6 \%$ ), and 35 people $(50 \%)$ of the respondents had nutritional status of obese. After the data were cross tabulation tested, the result showed that 27 female $(38.6 \%)$ and 8 male (11.4\%) suffered from obese. This fat composition causes female are easily to be getting fat which is associated with the risk of being obesity. Moreover, the fat composition of female is higher than that of male; so that, the fat is accumulated in the body of the patient. The number of female respondents was greater than that of male might possibly be caused by the time of collecting data which was done during working hours resulted most respondents were housewives who did not work.

\section{Waist Circumference ofTthe Respondents}

The data collected based on waist circumference showed that $55(78.6 \%)$ of the respondents mostly suffered from central obesity. This finding is in line with other research stated that $62 \%$ of respondents have abnormal waist circumference or central 
obesity in India [15]. Waist Circumference have the strongest association with BGL [16]. However, this result was not consistent with the others finding that the relationship between anthropometric values and blood glucose levels obtains different results, the result showed that among $61.4 \%$ respondents with normal waist circumference, $38.6 \%$ of which have central obesity [3]. This difference was due to the classification of waist circumference values specified in that study did not correspond to the physical characteristic of the local people; even though, the number of respondents and the waist circumference cut-off used in this study was the same. Moreover, the difference might also be influenced by the method of measuring the waist circumference.

\section{Waist-Hip Circumference Ratio of The Respondents}

The result of the research on 70 respondents indicated that based on waist-hip circumference ratio 51 people $(72.9 \%)$ had central obesity. This result was consistent with a reseach in East Java that 49 $(81.7 \%)$ of the respondents have abdominal obesity (central) based on waist-hip circumference ratio (male> 0.9 and female> 0.9) [16]. However, it was different from the another that identified the number of respondent whose waist-hip circumference ratio is abnormal or indicate abdominal obesity $(\geq 0.9$ men, women $\geq 0.85$ ) is $24.4 \%$ [3]. The difference result was caused by different sample characteristics and different research methods, as well as measuring waist-hip circumference ratio is more complicated than measuring waist circumference.

\section{E. Relationship between Body Mass Index (BMI) and Blood Glucose Level (BGL)}

The Spearman Correlation Test, $\mathrm{p}$ value $>0.05(\mathrm{p}=$ $0.129)$, concluded that there was no relationship or correlation between BMI and BGL. This study was in line with research done by Indrawati (2007) stated that there is no significant relationship between BMI and BGL [17].

This finding was in contrast with the results of the research conducted by Miftahul et. all (2011) who stated that there is a significant correlation between $\mathrm{BMI}$ and BGL; the higher the BMI the higher the BGL [12]. Moreover, the result of this study was also not in accordance with the research who claimed that there is a significant relationship between BMI and BGL [18]. In his research, there is a positive and significant correlation between BMI and Type 2 diabetes.

People who are getting overweight are getting level of leptin in their body increase. Leptin is a hormone associated with obesity gene. Leptin acts in the hypothalamus to regulate body fat levels, the ability to burn fat into energy, and the satiated feeling. The leptin plasma level increases as the body weight raises. Leptin works on the peripheral and central nervous system. Leptin might create resistance by blocking the phosphorylation of insulin receptor substrate-1 (IRS) that inhibit glucose uptake resulting in the increase of BGL [19].

The result of this study showed there was no correlation between BMI and BGL on the ground that the BMI measurement did not indicate the distribution of body fat. The BMI measurement has a limitation when it is applied to muscular and bigboned people who may have a high BMI but healthy, elder people who have low muscle mass with normal BMI [16].

Moreover, the amount and distribution of body fat could not describe the state of carbohydrate metabolism in the body. Theoretically, the increase of the amount of the body fat could cause insulin resistance; one of the main factors causing the increase of BGL. This phenomenon could be explained by pathophysiology of the emergence of the diabetes mellitus type 2 . In the initial phase in which insulin resistance has occurred, the pancreas increases insulin secretion so that blood glucose levels can still be maintained within normal levels. In the late phase in which pancreatic cells become "fatigue", the insulin secretion decreases gradually so that mild to severe fasting hyperglycemia arises [20]. This explanation described the cause of high rate of obesity, but the low rate of glucose metabolism abnormalities which possibly due to the short duration of being in obese among the respondents.

\section{F. Relationship between Waist Circumference and BGL}

This study concluded that there was a correlation between waist circumference and blood glucose level ( $p<0.05)$ which is in line with the finding of research that the relationship between blood glucose 
level and waist circumference, hip circumference, and waist-hip circumference ratio among adults in Nigeria showed that there is a positive relationship between waist circumference and blood glucose level $(r=0.1, p=0.004)$ [21]. The result of this study was consistent with another research about waist circumference as a predictor for blood glucose level in adults that waist circumference predicts significantly the levels of glucose in the blood and is used as the best predictor of screening in Diabetes mellitus type $2(\mathrm{p}=0.026)$ [22].

This finding different from the one that claimed that there is a weak positive correlation between waist circumference and blood glucose levels ( $\mathrm{r}=$ 0.168 and $p>0.05$ ) [3]. The correlation between waist circumference and blood glucose levels in male and female groups is respectively $r=0.009$ and $r=0.128$. However, the significance test of correlation coefficient ( $r$ ) shows that the value of $r$ in both groups was statistically insignificant ( $p>0.05$ for both men and women).

The relationship between waist circumference and BGL was due the fact that waist circumference described central obesity and subcutaneous and visceral abdominal fat. Visceral fat is generally used to describe intra-abdominal fat consisting of intra peritoneal and retroperitoneal fat. Central obesity causes the exposure of getting diabetes 2.26 times higher than that of non-obese [23]. This situation is associated with visceral fat tissue in which fat cells around the organs inside the abdomen increase the levels $\mathrm{TNF} \alpha$ (tumor necrotic factor alpha) plasma and change $\mathrm{TNF} \alpha$ to produce inflammatory cytokines and stimulate cells through interaction with its receptor markers to be insulin resistance.

The lipolytic activity which is greater than visceral fat in both obese and non-obese is the largest contributor of free fatty acids in the circulation [9]. The increased level of free fatty acids in plasma cause the distribution of the free fatty acid through portal system to liver is excessive; as a result, more fatty acids are oxidized and produce Acetyl CoA that activates pyruvate carboxylase enzyme in the liver. The pyruvate carboxylase enzyme functions to change the pyruvic acid to glucose by gluconeogenesis process resulting in the production and the release of glucose in the liver increase. The increase of gluconeogenesis can inhibit the action of insulin in the liver causing insulin resistance [9].

\section{G. Relations Waist-Hip Ratio with KGD}

The result of the research found the correlation between waist circumference and blood glucose level ( $\mathrm{p}<0.05)$. This finding was in line with the one that stated that there is a positive relationship between blood glucose level and waist-hip circumference ratio $(r=0.1$ and $p=0.002)$ [21]. Meanwhile, another research reported that patients with hyperglycemia have a wide waist circumference (central obesity); the wider the waistto-hip circumference ratio the greater the plasma glucose levels [25]. There is a link between waist-hip circumference ratio and blood glucose level $(\mathrm{p}=$ 0.002 and $r=0.392$ ) [16].

The relationship between Waist-Hip Circumference Ratio and BGL could be explained as waist-hip circumference ratio could be use as indicator representing the distribution of fat rather than the total amount of the body fat. Waist-Hip Circumference Ratio, beside waist circumference, could also determine the central obesity. Therefore, the distribution of the body fat was important to be used as a predictor of diabetes than the general obesity. Upper body adipose tissue measured by waist-hip circumference ratio had a closer relationship with diabetes in several cross-sectional and prospective studies.

Considering the higher increase of free fatty acids plasma causing the accumulation of lipid intramioseluler, the metabolites produced resulted in the reduction of insulin receptor. The excessive lipid accumulation in the pancreatic $\beta$ cells could cause dysregulation of insulin secretion. The dysregulation of insulin secretion depends closely on time; therefore, the secretion of insulin will increase in short-term lipids accumulation, but decrease in the long-term accumulation of a chronic nature. Furthermore, the abnormality of pancreatic $\beta$ cells due to free fatty acids causes apoptosis of those cells [25].

\section{CONCLUSION}

There is a positive correlation between $\mathrm{WC}$ and BGL, and BGL and WHCR. The greater the WC and WHCR of a person the riskier the person to suffer 
from metabolic disorders of diabetes will be. The risk of a person whose waist hip circumference ratio is above normal is 20 times more to be exposed to diabetes. By controlling anthropometric, the risk of the people living surround community health centers Tuntungan to suffer from diabetes will reduce. The anthropometric control efforts can include diet control and regular exercise. It is expected that the management of the clinic can people to live healthier to reduce the risk of being exposed to metabolic disease.

\section{ACKNOWLEDGEMENT}

I would like to extend my appreciation to the Rector of Sumatra Utara University and the Dean of the Faculty of Medicine, Sumatra Utara University.

\section{REFERENCES}

[1] R. Soegih and K. Wiramihardja, Obesitas Permasalahan Dan Terapi Praktis. Jakarta : Sagung Seto, 2009

[2] Departmen oh Health of Indonesia . Riset Kesehatan Dasar (RISKESDAS). Jakarta : Departemen Kesehatan RI, 20072007

[3] N. I. Lipoeto, E. Yerizel, Z. Edward, and I. Widuri, Hubungan Nilai Antropometri dengan Kadar Glukosa Darah. Medika, Januari, hal 23 -28. (2007). Available: http://repository.unand.ac.id/49/1/ gula darah danantro.pdf. accessed on: 30/08/2016.

[4] PERKENI 2011. Konsensus Pengelolaan dan Pencegahan Diabetes Melitus Tipe 2 di Indonesia, Pengurus Besar Perkumpulan Endokrinologi Indonesia

[5] H. A. Damanik, Potensi Tempe Kedelai dalam Terapi Nutrisi Medik Pada Obesitas Dewasa Dengan Komorbid. Pidato Pengukuhan Jabatan Guru Besar Tetap. Universitas Sumatra Utara. Sumatra, 2009.

[6] D. H. Dwi. Hubungan Antara Indeks Massa Tubuh (IMT) dan Lingkar Lengan Atas (LILA) dengan Kadar Gula Darah dan Kolesterol Pada Wanita Usia Subur (WUS) di Kecamatan Cangkringan Kabupaten Sleman. Surakarta : Fakultas Ilmu Kesehatan Universitas Muhammadiyah Surakarta, 2012

[7] M. Astawan, (2006). Hipoglikemia. [online]. Available: http//www.google.co.id/medicastore.com

[8] S. Martin, S. P. Marinho, The Potential of central obesity antropometric indicators as diagnostic tools. Revista de Saude Publica, 2003

[9] W. Yuliasih, Obesitas Abdominal Sebagai Faktor Risiko Peningkatan Kadar Glukosa Darah. Semarang : Fakultas Kedokteran Universitas Diponegoro, 2003

[10] Garrows. Obesity in Human Nutrition and Dietetics, Chuechill, Livingstone, 2000

[11] D. Irawan, Prevalensi dan Faktor Risiko Kejadian Diabetes Melitus
Tipe 2 di Daerah Urban Indonesia (Analisa Data Sekunder Riskesdas 2007). Thesis Universitas Indonesia, 2010

[12] Miftahul, et all, Hubungan Indeks Masa Tubuh (IMT) Dengan Kadar Gula Darah Penderita Diabetes Mellitus (DM) Tipe 2 Rawat Jalan Di RS Tugurejo Semarang, 2011

[13] Nyoman Sujaya, Pola Konsumsi Makanan Tradisional Bali sebagai Faktor Risiko Diabetes MelitusTipe 2 di Tabanan Jurnal Skala Husada Vol. 6 No.1 hal:75-81, 2009

[14] Kusniawati, Analisis faktor yang berkontribusi terhadap self care diabetes pada klien diabetes melitus tipe 2 di rumah sakit umum tangerang. Tesis, Program Magister Keperawatan Universitas Indonesia, 2011.

[15] Patil, et al, Korelasi Gula Darah dengan Lingkar Pinggang dan Indeks Massa Tubuh di Populasi India. Mumbai : Global J. Pharmacol., 6 (1) 08-11, 201..

[16] N. Septyaningrum, S. Martini, Waist Circumference as The Strongest Factor Related to Blood Glucose Level (Lingkar Perut Mempunyai Hubungan Paling Kuat dengan Kadar Gula Darah). Surabaya : Jurnal Berkala Epidemiologi; 2; 1, 2014

[17] N. Indrawati, Faktor-Faktor yang Berhubungan dengan Kejadian Diabetes Melitus Tipe 2 (Skripsi). Semarang : Universitas Diponegoro, 2007

[18] L. Purnawaty, Hubungan IMT dengan Kejadian Diabetes Melitus tidak tergantung Insulin pada Pasien Rawat Jalan di RSUPN Cipto Mangunkusumo pada tahun 1998. Tesis : Universitas Indonesia, 1998

[19] P. J. D'adamo. Diet Sehat Diabetes Sesuai Golongan Darah. Yogyakarta : Delapratasa. 2008

[20] N. Suastika. Metabolic Syndrome Rural Population of Bali. International Journal of Obesity and Related Metabolic Disorders. 28:S55.9. Lin. W.Y., Lee, W.T. Chen, C.Y., et al. 2002. Optimal Cutoff Values For Obesity; Using Simple Anthropometric Indeces to Predict Cardiovascular Risk Factors in Taiwan. Int J Obes Relat Metab Disord. 26:1232-1238, 2004

[21] E. A. Etukamana, F. H. Puepet, M. O. M. O. Obadofin, Relationship of Blood Glucose Levels With Waist Circumference, Hip Circumference And Waist-Hip Ratio Among Rural Adults In Nigeria. Plateu State : Asian Journal of Pharmaceutical And Clinical Research; $7 ; 1,2014$

[22] Hardiman et. al. Waist circumference as a predictor for blood glucose levels in adults. Jakarta : Universa Medicina; 28;2, 2009

[23] F. Soetiarto, S. Roselinda, Hubungan Diabetes Mellitus dengan Obesitas Berdasarkan Indeks Massa Tubuh dan Lingkar Pinggang Data Riskesdas 2007. Buletin Penelitian Kesehatan (Online), Vol. 38 , No. 1, Hlm. 36-42, (http://ejournal.litbang). Diakses 23 September 2016. 2010

[24] N. Mayasari, dan Y. Wirawanni, Hubungan Lingkar Leher dan Lingkar Pinggang dengan Kadar Glukosa Darah Puasa Orang Dewasa : Studi Kasus di SMA Negeri 2 Semarang dan SMP Negeri 9 Semarang. Semarang : Journal Of Nutrition College; 3; 4; 473-481, 2014

[25] Syukran, Mardianto, D. Lindarto, et all, Sindroma metabolic pada karyawan/ staf perkebunan. Naskah Lengkap The Mets, Surabaya Metabolic Syndrome Update-1 (SUMETSU -1). 105, 2004. 